\title{
THE EFFECT OF GROWING SEASONS ON SOME AGRONOMIC AND QUALITY CHARACTERISTICS OF SOYBEAN VARIETIES IN MEDITERRANEAN REGION IN TURKEY
}

\author{
Halil BAKAL $L^{1}$, Leyla GULLUOGLU ${ }^{1}$, Bihter ONAT ${ }^{2}$, Halis ARIOGLU ${ }^{*}$ \\ ${ }^{I}$ Cukurova University, Faculty of Agriculture, Dep. of Field Crop, Adana, TURKEY \\ ${ }^{2}$ Cukurova University, Vocational School of Kozan, Adana, TURKEY \\ *Corresponding author: halis@cu.edu.tr
}

Received: 21.04.2017

\begin{abstract}
This study was conducted at the Experimental area of Cukurova University in 2013 and 2014 as a main and double crop growing seasons. The objective of this study was to determine the effect of growing seasons on some agronomic and quality characteristics of soybean (Glycine max Merr.) varieties in Mediterranean Region in Turkey. The experimental design was a Randomized Complete Block with three replications. The Arisoy, Atakisi, Ataem-7, Umut-2002, Turksoy, Adasoy, Cinsoy, Ilksoy, Sa-88, S.4240, Blaze and Nova varieties were used as a plant material in this research. The investigated characteristics such as plant height, pod and branch number per plant, the lowest pod height, 1000-seed weight, oil percentage and oil yield values of soybean varieties were higher in main crop than in double crop, whereas the protein percentage values was higher in double crop. The average seed yield of soybean varieties were $4616 \mathrm{~kg} \mathrm{ha}^{-1}$ in main crop and it was decreased to $4164 \mathrm{~kg} \mathrm{ha}^{-1}$ in double crop growing season. The average seed yield was higher in main crop than in double crop. According to a two-year average, the seed yield per hectare of soybean varieties was varied between 4323-5377 kg ha-1 in main crop and 3194-4667 kg ha-1 in double crop growing season, and the highest seed yield was obtained from Atakisi and Arisoy varieties in both growing seasons.
\end{abstract}

Key words: Soybean variety, seed yield, growing season, agronomic and quality characteristic

\section{INTRODUCTION}

Soybean (Glycine max Merr.) is one of the most important legume crops grown in tropical, subtropical and temperate climate (Arioglu, 2014). Soybean seeds contain $18-24 \%$ oil, $36-40 \%$ protein, $26-34 \%$ carbohydrates and 5$8 \%$ minerals (Lanna et al., 2005 and Arioglu, 2014). For this reason, it is an important source of edible vegetable oil and high quality vegetable protein for human nutrition and animal feeding in the world. The share of the soybean seed was $60 \%$ in the total oil seeds production in the world in 2015 (FAO, 2015). Soybean improves soil fertility by fixing atmospheric nitrogen due to legume crop (Arioglu, 2014).

The growth and development of soybean plant is affected by the environmental factors such as temperature and photoperiod. $\mathrm{Hu}$ and Wiatrak (2012) reported that delayed planting date and unfavorable environmental conditions have a negative effect on growth, development and yield of soybean. Changes in photoperiod, temperature and precipitation with delayed planting affect the duration of vegetative and reproductive stages, number of branches and pods, plant height, leaf area index and grain yield. These two researchers also reported that photoperiod is one of the most important environmental factors, because it regulates the whole developmental processes of soybean plant. Shortened vegetative and reproductive stages due to changes in photoperiod with delayed planting, contribute to yield loss. Hicks (1978) reported that flower initiation is controlled by photoperiod, temperature, and genotype in soybean plant. The main effect of day length on soybean development is that of flowering induction. Soybeans are classified as short-day plants because short days initiate the flowering process. The length of the dark period is the controlling factor in floral induction. With continued long days, soybeans will remain vegetative almost indefinitely. Board et al. (1992) reported that the number of days to flowering and maturity reduce and the length of regulative and reproductive periods of development decrease in short-day conditions. Whigham and Minor (1978) reported that differences in day length result in responses in term of the number of days to flower, the number of days to maturity, plant height, seed weight, pod number, branch number and node number. Flowering occurs when the day length becomes shorter than the critical value for 
the cultivar. Late maturing cultivars are more sensitive to photoperiod than early maturing cultivars.

Sadeghi and Niyaki (2013) reported that generally, the time of planting varies depending on the climate condition of the region and the variety to be grown. Different varieties of soybean are sensitive to change to environment conditions where the crop is being grown. Zargar et al. (2011) reported that delayed planting dates can accelerate flowering, shorten vegetative and reproductive growth, reduced grain yield and oil content of soybean. Generally, long growing season allows plants to accumulate more dry matter through more vegetative growth.

Minor (1976) reported that the date of planting is one of the most critical cultural practices in soybean production. As planting is delayed during the summer season, time to maturity is shortened. Normally the lifecycle duration of late varieties is reduced more than that of early varieties. The growth and yield responses of soybean to planting date depend on the environment, variety and production practice. Caliskan et al. (2007) reported that seed yield reduction in late planted soybean was attributed to shorter day length. Sadeghi and Niyaki (2013) reported that the soybean cultivars with early sowing (April 30) produced gave higher yield and quality as compared to the late sowing date (May 20).

The composition of soybean seed depends on many factors, including genotype, growing season, geographic location, and agronomic practices. The environment plays a critical role in oil content. Seed-fill is the most critical growth stage for environmental effects temperature and is the primary factor. Oil begins to accumulate in developing seeds 15-20 days after flowering. The most rapid deposition occurs 20-40 days after flowering and continues until 70 days after flowering (Chu and Sheldon, 1979; Gibson and Mullen, 1996 and Bellaloui et al., 2013). Wolf et al. (1982) reported that oil and protein content of soybean seed was affected by the growth temperature, and the oil content was increased while the protein content was decreased at the high temperature. Bellaloui et al. (2011) found out that under irrigated conditions early planting (April) increased seed oil but decreased protein content.

Soybean grown as a main cropped and as a double cropped after a small grain harvest in the Cukurova region (Mediterranean region) in Turkey. The agronomic and quality characteristic of soybean varies depending on growing seasons and varieties. The objective of this study was to determine the effect of growing seasons on some agronomic and quality characteristics of soybean varieties in Mediterranean region in Turkey.

\section{MATERIALS AND METHODS}

\section{Experimental site and materials}

The field trials were conducted during the 2013 and 2014 two consecutive cropping seasons as a main and double crop at the experimental area of Cukurova University in Adana, Turkey (Southern Turkey, $36^{0} 59^{1} \mathrm{~N}$, $35^{\circ} 18^{1}$ E; 23 elevation). The Arisoy, Atakisi, Ataem-7, Umut-2002, Cinsoy, Sa-88, S.4240, Nova (Maturity group III) and Turksoy, Adasoy, Ilksoy, Blaze (Maturity group IV) varieties were used as a plant material in this research.

The soil in the experimental site is classified as clay loam texture. The soil tests in both years indicated a $\mathrm{pH}$ of 7.5 with high concentrations of $\mathrm{K}_{2} \mathrm{O}$ and low concentrations of $\mathrm{P}_{2} \mathrm{O}_{5}$. In addition, the organic matter and nitrogen content of the soil was very low. The lime content was $19 \%$ in the upper layers of the soil.

In Adana, winters are warm and rainy, whereas summers are dry and hot, which is a typical of a Mediterranean climate. The mean monthly air temperature during the research period (May-October) was 19.5 to $28.6^{\circ} \mathrm{C}$ in 2013 , whereas it was in the 21.0 to $29.1^{\circ} \mathrm{C}$ range in 2014. The total rainfall was $89.2 \mathrm{~mm}$ and $172.9 \mathrm{~mm}$ during the growing periods (main and double crop) in 2013 and 2014, respectively. The average relative humidity was ranged from $47.9 \%$ to $72.3 \%$ in 2013 and $62.9 \%$ to $72.6 \%$ in 2014 . The differences between the years and long term for the climatic data were not found very significant (Table 1).

Table 1. The climate conditions during the 2013-2014 growing period and long term (LT) average (1950-2015) (Anonymous, 2015)

\begin{tabular}{lccccccccc}
\hline \multirow{2}{*}{ Months } & \multicolumn{3}{c}{ Mean } & temperature $\left({ }^{\circ} \mathbf{C}\right)$ & \multicolumn{3}{c}{ Precipitation $(\mathbf{m m})$} & \multicolumn{3}{c}{ Relative humidity $(\%)$} \\
\cline { 2 - 10 } & $\mathbf{2 0 1 3}$ & $\mathbf{2 0 1 4}$ & $\mathbf{L T}$ & $\mathbf{2 0 1 3}$ & $\mathbf{2 0 1 4}$ & LT & $\mathbf{2 0 1 3}$ & $\mathbf{2 0 1 4}$ & LT \\
\hline May & 22.7 & 21.3 & 21.7 & 57.4 & 22.4 & 47.6 & 72.3 & 70.4 & 66.9 \\
June & 25.3 & 24.8 & 25.6 & 0.3 & 1.7 & 19.8 & 65.7 & 70.5 & 68.0 \\
July & 28.2 & 28.2 & 28.1 & 0.0 & 0.3 & 7.0 & 65.2 & 72.6 & 71.6 \\
August & 28.6 & 29.1 & 28.5 & 0.0 & 0.3 & 5.3 & 69.0 & 70.3 & 71.0 \\
September & 25.3 & 25.9 & 25.9 & 15.0 & 80.4 & 17.6 & 63.1 & 64.1 & 65.4 \\
October & 19.5 & 21.0 & 21.3 & 16.5 & 67.8 & 40.6 & 47.9 & 62.9 & 61.6 \\
\hline
\end{tabular}

\section{The experiment treatments}

The study design was a Randomized Complete Block with three replication, separately in main and double crop. Before sowing, $200 \mathrm{~kg} \mathrm{ha}^{-1}$ of DAP $\left(36 \mathrm{~kg} \mathrm{ha}^{-1} \mathrm{~N}, 92\right.$ $\mathrm{kg} \mathrm{ha}^{-1} \mathrm{P}$ ) was applied in both cropping system. Fertilizer requirements were determined based on the nutritional requirements of soybean and soil nutrient availability. Additional nitrogen fertilizer was applied (side-dressing) as a rate of $66 \mathrm{~kg} \mathrm{ha}^{-1}$ in the form of Ammonium nitrate $(33 \% \mathrm{~N})$ before first irrigation (R1 stage). Weed control was at both years with a pre-plant application of Dual 
(Metolachlor) at amount of $1.51 \mathrm{ha}^{-1}$. The plot size was $14.0 \mathrm{~m}^{2}(2.8 \mathrm{~m} \times 5.0 \mathrm{~m})$ consisting of four rows, five meter long and $70 \mathrm{~cm}$ apart. The soybean seeds were planted as a high density at planting and then plant distance (plant density) was regulated $(4 \mathrm{~cm})$ by pulling out plants (thinning) at the V2 growth stage in both growing seasons. Before planting, all seeds were inoculated with Rhizobium bradyrhijaponicum bacteria. The planting and harvesting dates were May 5 and September 15 in main cropping and June 15 and October 15 in double cropping system, respectively. During the growing period, recommended pesticides and fungicides were applied to control insects and diseases. During the growing period, other standard cultural practices were applied at proper time intervals. The plants harvested by hand when the pods and plants are matured in both growing seasons.

\section{Data collection and measurement}

Plant height $(\mathrm{cm})$, the lowest pod height $(\mathrm{cm})$, branch and pod number per plant (no. plant ${ }^{-1}$ ) were collected from 10 plants randomly selected from each plot at the harvesting time. Yield data per plot was measured in a similar way from all remaining plants excluding the very end on each side of the four rows. 1000-seed weight $(\mathrm{g})$ data was obtained after harvesting (Zaimoglu et al., 2004). The oil and protein percentage $(\%)$ was estimated according to Association of Official Analytical Chemists (AOAC, 2010). Oil yield was calculated as the ration of seed yield $\left(\mathrm{kg} \mathrm{ha}^{-1}\right) \mathrm{x}$ oil content (\%) (Gulluoglu et al., 2016).

The data were statistically analyzed by JUMP 8.1.0 statistical software with Split Plot design. Least Significant Differences (LSD) test was used to compare the treatments at probability level of 0.05 .

\section{RESULTS AND DISCUSSIONS}

The two years average data belonging to plant height, the lowest pod height, branch and pod number per plant, 1000-seed weight, seed yield, oil and protein content and oil yield of soybean varieties at different growing seasons has been presented in Table 2, 3 and 4 .

\section{Plant height}

It can be seen in Table 2, the average plant height was $118.8 \mathrm{~cm}$ in main crop and $110.8 \mathrm{~cm}$ in double crop. The differences between the growing seasons were statistically significant for plant height. The plant height was affected significantly by growing seasons. Generally, the plant height in main crop was higher when compared to double crop. Hicks (1978) reported that soybeans are classified as short-day plants because short days initiate the flowering process and effects on growing period. The vegetative growing period of soybean plant is shorter in short-day condition. For this reason the plants start to flower after emergence very soon in these conditions. The growing period in main crop was between May and September, but in double crop it was between June and October. The long day conditions effectives on vegetative growth of soybean in main crop, whereas short day effectives in double crop growing season in Mediterranean region. Zargar et al. (2011) reported that delayed planting dates can accelerate flowering, shorten vegetative and reproductive growth. Hu and Wiatrak (2012) reported that delayed planting date and unfavorable environmental conditions have a negative effect on soybean growth, development and yield. Changes in photoperiod and temperature with delayed planting affect the duration of vegetative and reproductive stages, number of branches and pods and plant height. Similar results were reported by other researchers (Whigham and Minor, 1978; Oplinger and Philbrook, 1992; Kang et al., 1998; Pedersen and Laure, 2003; Caliskan et al., 2007 and Rehman et al., 2014).

Table 2. The data belonging to plant height, the lowest pod height and branch number per plant of two years (2013-2014) average values of some soybean varieties grown in different seasons

\begin{tabular}{|c|c|c|c|c|c|c|}
\hline \multirow{3}{*}{ Varieties (A) } & \multicolumn{2}{|c|}{$\begin{array}{l}\text { Plant height } \\
\text { (cm) }\end{array}$} & & \multicolumn{2}{|c|}{ Branch number (no.plant- ${ }^{1}$ ) } \\
\hline & & & Growi & easons (B) & & \\
\hline & Main Crop & Double Crop & Main Crop & Double Crop & Main Crop & Double Crop \\
\hline Arısoy & 111.2 & 108.8 & 22.6 & 20.6 & 3.7 & 2.5 \\
\hline Atakisi & 120.0 & 114.7 & 19.8 & 18.1 & 3.1 & 2.2 \\
\hline Ataem-7 & 129.5 & 123.4 & 17.6 & 17.0 & 3.2 & 2.7 \\
\hline Umut-2002 & 135.8 & 120.9 & 21.1 & 19.2 & 3.3 & 3.0 \\
\hline Turksoy & 124.8 & 110.6 & 17.6 & 16.2 & 4.1 & 2.0 \\
\hline Adasoy & 123.2 & 111.9 & 19.3 & 18.0 & 3.3 & 2.3 \\
\hline Cinsoy & 107.4 & 103.9 & 18.5 & 17.5 & 4.0 & 2.2 \\
\hline Ilksoy & 103.3 & 96.3 & 20.9 & 20.0 & 4.1 & 2.1 \\
\hline Sa- 88 & 123.1 & 114.2 & 17.6 & 16.2 & 3.8 & 2.2 \\
\hline S. 4240 & 126.8 & 120.4 & 20.4 & 18.8 & 3.7 & 2.1 \\
\hline Blaze & 110.0 & 93.6 & 17.1 & 15.0 & 3.6 & 2.0 \\
\hline Nova & 110.5 & 110.7 & 18.3 & 17.6 & 3.5 & 3.0 \\
\hline Average & 118.8 & 110.8 & 19.3 & 17.9 & 3.6 & 2.3 \\
\hline $\operatorname{LSD}\left(\% 5_{\mathrm{A}}\right)$ & 3.57 & 3.45 & 0.82 & 1.03 & 0.37 & 0.39 \\
\hline $\operatorname{LSD}\left(\% 5_{\mathrm{B}}\right)$ & \multicolumn{2}{|c|}{3.46} & \multicolumn{2}{|c|}{0.69} & \multicolumn{2}{|c|}{0.83} \\
\hline $\operatorname{LSD}\left(\% 5_{\mathrm{AxB}}\right)$ & \multicolumn{2}{|c|}{3.41} & \multicolumn{2}{|c|}{ NS } & \multicolumn{2}{|c|}{0.37} \\
\hline
\end{tabular}


The plant height values of soybean varieties varied between 103.3-135.8 $\mathrm{cm}$ in main crop and 93.6-123.4 cm in double crop growing season in a two-year average. The differences between the varieties for the plant height were significant in both growing seasons. The lowest and the highest plant height was obtain from Ilksoy $(103.3 \mathrm{~cm})$ and Umut-2002 $(135.8 \mathrm{~cm})$ in main crop and from Blaze $(93.6 \mathrm{~cm})$ an Ataem-7 $(123.4 \mathrm{~cm})$ in double crop growing season (Table 2). Minor (1976) reported that the date of planting is one of the most critical cultural practices in soybean production. As planting is delayed during the summer season, time to maturity is shortened. Normally the life-cycle duration of late varieties is reduced more than early varieties. Hicks (1978) reported that flower initiation and growing period is controlled by photoperiod, temperature, and genotype in soybean plant. Sadeghi and Niyaki (2013) reported that different varieties of soybean are sensitive to change to environment conditions where the crop is being grown. They also reported that the plants have less vegetative growth, shorter stem and lower reproductive nodes at the late planting. Whigham and Minor (1978) reported that soybean cultivars differ in their response to day length. Differences in day length result in responses in term of the number of days to flower, the number of days to maturity, plant height, seed weight, pod number, branch number, node number and others. Late maturing cultivars are more sensitive to photoperiod than are early maturing cultivars. These findings are supported by Whigham and Minor (1978), Oplinger and Philbrook (1992), Kang et al. (1998), Caliskan et al. (2007), Zargar et al. (2011), Rehman et al. (2014) and Matsuo et al. (2016).

The interaction between the growing season and variety for the plant height was statistically significant. The plant height of soybean varieties were affected from the environment conditions during the growing period. Whigham and Minor (1978) reported that there is usually a positive association between day length and plant height. The highest plant height was obtained from Umut-2002 in main crop and from Ataem-7 in double crop growing season (Table 2).

\section{The lowest pod height}

The differences between the growing seasons for the lowest pod height were statistically significant. The average lowest pod height values were found $19.3 \mathrm{~cm}$ and $17.9 \mathrm{~cm}$ in main and double crop, respectively (Table 2). The lowest pod height in main crop was higher when compared to double crop.

The long day conditions effectives on vegetative growth of soybean in main crop, whereas short day effectives in double crop growing season in Mediterranean region. Hicks (1978) reported that flower initiation is controlled by photoperiod, temperature, and genotype in soybean plant. The main effect of day length on soybean development is that of flowering induction. Soybeans are classified as short-day plants because short days initiate the flowering process. Whigham and Minor (1978) reported that soybean cultivars differ in their response to day length. Differences in day length result in responses in term of the number of days to flower, the number of days to maturity, plant height, seed weight, pod number, branch number and node number. Flowering occurs when the day length becomes shorter than the critical value for the cultivar. Late maturing cultivars are more sensitive to photoperiod than are early maturing cultivars. As mentioned above, soybean is a short-day plant. For this reason the plants were started to flowering very soon after emergence in double crop growing season and the pods were formed closer to soil surface. The flowering of plants was delayed due to long day conditions in main crop growing season and the pods were formed higher up the stem. Similar results were reported by other researchers (Board et al., 1992; Kang et al., 1998; Zargar et al., 2006; Caliskan et al., 2007 and Boquet and Clawson, 2007).

The average lowest pod height values of soybean varieties varied between $17.1-22.6 \mathrm{~cm}$ in main crop and $15.0-20.6 \mathrm{~cm}$ in double crop growing seasons. The differences between the varieties for the lowest pod height were statistically significant in both growing seasons. The lowest pod height was highest in Arısoy $(22.6 \mathrm{~cm}$ and $20.6 \mathrm{~cm}$ ) in both growing seasons Table 2). The pods were formed higher up the stem in main crop compared to double crop. Hicks (1978) and Whigham and Minor (1978) reported that flower initiation is controlled by photoperiod, temperature and genotype in soybean plant, and that soybean cultivars differ in their response to day length. They also indicated that the flowering occurs when the day length becomes shorter than the critical value for the cultivar. Late maturing cultivars are more sensitive to photoperiod than are early maturing cultivars. The interaction between the growing season and variety for the lowest pod height was not statistically significant. The results are corresponded well with the findings of Zargar et al. (2011), Bonquet and Clawson (2007), Caliskan et al. (2007), and Sadegi and Niyaki (2013).

\section{Branch number per plant}

It can be seen in Table 2, the average branch number per plant was found 3.6 no. plant $^{-1}$ in main crop and 2.3 no. plant $^{-1}$ in double crop. The differences between the growing seasons were statistically significant for branch number. The branch number per plant was affected significantly by the growing seasons. The branch number in main crop was greater $(56.5 \%)$ when compared to double crop.

Sadeghi and Niyaki (2013) reported that the plants have less vegetative growth, shorter stem and lower reproductive nodes at the late planting. Whigham and Minor (1978) reported that soybean cultivars differ in their response to day length. Differences in day length result in responses in term of the number of days to flower, the number of days to maturity, plant height, seed weight, pod number, branch number and node number. As indicated by Whigham and Minor (1978) and Sadeghi and Niyaki (2013), in short day condition, the soybean plants produce less vegetative growth than long day conditions due to soybean is a short day plant. Hu and Wiatrak 
(2012) reported that delayed planting date and unfavorable environmental conditions have a negative effect on soybean growth, development and yield. Changes in photoperiod and temperature with delayed planting affect the duration of vegetative and reproductive stages, number of branches and pods and plant height. For this reason, the branch number per plant was greater in main crop than in double crop.

The differences between the varieties were significant for the branch number per plant in both growing seasons. The branch number of soybean varieties was varied between 3.1-4.1 no. plant ${ }^{-1}$ in main crop and 2.0-3.0 no. plant ${ }^{-1}$ in double growing season. The soybean varieties were affected from growing seasons. The branch number values were found higher in main crop than in double crop. Whigham and Minor (1978) reported that soybean cultivars differ in their response to day length. Differences in day length result in responses in term of the number of days to flower, the number of days to maturity, plant height, seed weight, pod number, branch number and node number. Sadeghi and Niyaki (2013) reported that different varieties of soybean are sensitive to change to environment conditions where the crop is being grown. They also reported that the plants have less vegetative growth, shorter stem and lower reproductive nodes at the late planting (short-day conditions). As mentioned above, soybean plants are sensitive to change to environment conditions such as temperature and photoperiod. The plants were produced less vegetative growth in double crop than in main crop growing season. For this reason, the branch number per plant was found lower in double crop growing. Similar results were reported by Kang et al. (1998) and Caliskan et al. (2007).
The interaction between the growing season and variety for branch number per plant was found statistically significant. The highest branch number value was obtained from Turksoy and Ilksoy (4.1 no. plant $\left.{ }^{-1}\right)$ in main crop and from Nova and Umut-2002 (3.0 no. plant $\left.{ }^{-1}\right)$ in double crop growing season (Table 2).

\section{Pod number per plant}

It can be seen in Table 3, the average pod number per plant was 48.2 pods plant $^{-1}$ in main crop and 46.3 pods plant $^{-1}$ in double crop. The differences between the growing seasons were statistically significant for pod number. The pod number per plant was affected significantly by growing seasons. The number of pods per plant in main crop was higher when compared to double crop. Whigham and Minor (1978) reported that the differences in day length result in responses in term of the number of days to flower, the number of days to maturity, plant height, seed weight, pod number, branch number and node number. Board et al. (1992), Zargar et al. (2011) and Sadeghi and Niyaki (2013) reported that soybean is a short-day plant and the number of days to flowering and maturity reduce and the length of vegetative and reproductive period of development decrease in short day conditions. Hu and Wiatrak (2012) reported that delayed planting date and unfavorable environmental conditions have a negative effect on soybean growth, development and yield. Changes in photoperiod and temperature with delayed planting affect the duration of vegetative and reproductive stages, number of branches and pods and plant height. As mentioned above by some researchers, soybean is a short-day plant, and vegetative and reproductive growing stages were reduced in double crop growing season. For this reason, the pods number per plant was decreased in this condition.

Table 3. The data belonging to pod number per plant, 1000-seed weight and seed yield per hectare of two years (2013-2014) average values of some soybean varieties grown in different seasons

\begin{tabular}{|c|c|c|c|c|c|c|}
\hline \multirow{3}{*}{ Varieties (A) } & \multicolumn{2}{|c|}{$\begin{array}{l}\text { Pod number } \\
\left(\text { pods plant }^{-1}\right)\end{array}$} & \multirow{2}{*}{\multicolumn{2}{|c|}{$\begin{array}{c}\begin{array}{c}\text { 1000-seed weight } \\
\text { (g) }\end{array} \\
\end{array}$}} & \multicolumn{2}{|c|}{$\begin{array}{c}\text { Seed yield } \\
\left(\mathrm{kg} \mathrm{ha}^{-1}\right)\end{array}$} \\
\hline & \multicolumn{5}{|c|}{ Growing seasons (B) } & \\
\hline & Main Crop & Double Crop & Main Crop & Double Crop & Main Crop & Double Crop \\
\hline Arısoy & 51.4 & 50.3 & 172.6 & 151.3 & 4982 & 4667 \\
\hline Atakisi & 55.7 & 51.2 & 167.4 & 148.6 & 5377 & 4662 \\
\hline Ataem-7 & 46.8 & 44.2 & 174.2 & 149.0 & 4667 & 3819 \\
\hline Umut-2002 & 47.4 & 46.2 & 171.1 & 152.5 & 4686 & 4346 \\
\hline Turksoy & 44.2 & 38.7 & 182.6 & 153.4 & 4435 & 3194 \\
\hline Adasoy & 50.6 & 50.2 & 171.4 & 139.6 & 4455 & 4138 \\
\hline Cinsoy & 43.5 & 42.7 & 190.5 & 140.8 & 4288 & 4287 \\
\hline Ilksoy & 45.2 & 43.2 & 174.5 & 143.9 & 4575 & 4242 \\
\hline $\mathrm{Sa}-88$ & 49.6 & 49.4 & 168.4 & 129.8 & 4517 & 3916 \\
\hline S. 4240 & 48.4 & 47.3 & 170.3 & 147.7 & 4553 & 4417 \\
\hline Blaze & 48.6 & 45.2 & 167.7 & 151.2 & 4529 & 4016 \\
\hline Nova & 47.1 & 46.5 & 169.0 & 147.5 & 4323 & 4271 \\
\hline Average & 48.2 & 46.3 & 173.3 & 145.8 & 4616 & 4164 \\
\hline $\operatorname{LSD}\left(\% 5_{\mathrm{A}}\right)$ & 3.89 & 2.59 & 3.75 & 5.99 & 237.29 & 205.07 \\
\hline $\operatorname{LSD}\left(\% 5_{\mathrm{B}}\right)$ & \multicolumn{2}{|c|}{1.13} & \multicolumn{2}{|c|}{2.75} & \multicolumn{2}{|c|}{154.77} \\
\hline $\operatorname{LSD}\left(\% 5_{\mathrm{AxB}}\right)$ & \multicolumn{2}{|c|}{ NS } & \multicolumn{2}{|c|}{4.85} & \multicolumn{2}{|c|}{234.79} \\
\hline
\end{tabular}


The differences between the varieties were statistically significant for the pod number per plant in both growing seasons. The pod number of soybean varieties was varied between 43.5-55.7 pods plant ${ }^{-1}$ in main crop and 42.7-51.2 pods plant ${ }^{-1}$ in double growing season. The pods number per plant was affected by the environment condition such as day length and air temperature. The soybean plants start to flower very soon after emergence in short day and high air temperature conditions. The flowering and pod formation period of soybean plant is shorter in short day conditions than in long day conditions. For this reason, the number of flower and pod formation reduces in these conditions. Zargar et al. (2011) and Sadeghi and Niyaki (2013) reported that delayed planting dates can accelerated flowering, shorten vegetative and reproductive growth of soybean. Generally, long growing season allows plants to accumulate more dry matter through more vegetative growth. Hicks (1978) reported that Flower initiation is controlled by photoperiod, temperature, and genotype in soybean plant. The main effect of day length on soybean development is that of flowering induction. The length of the dark period is the controlling factor in floral induction. With continued long days, soybeans will remain vegetative almost indefinitely. Because soybean cultivars do not all have the same critical day length, the effect of planting date on the number of days to flowering and days to maturity will be different for different cultivars. The period from flowering to maturity for the late cultivars was unaffected by planting date, but the period was reduced for the earliest cultivars. The number of pods per plant was considerably higher for each cultivar during the longer day length season (Whigham and Minor 1978). As mentioned above by some researchers, photoperiod affects pod production efficiency and seed filling rate in soybean plant. In this research, the number of pods per plant of soybean varieties was found higher in main crop than in double crop. The interaction between the growing season and variety for pod number per plant was not found statistically significant. The results are corresponded well with the findings of Whigham and Minor (1978), Caliskan et al. (2007), Zargar et al. (2011), Puteh et al. (2013), Sadegi and Niyaki (2013) and Matsuo et al. (2016).

\section{0-Seed weight}

The effect of growing season on the 1000-seed weight was found significant. The average thousand seed weight of soybean varieties was $173.3 \mathrm{~g}$ in main crop and was $145.8 \mathrm{~g}$ in double crop growing season (Table 3 ). The 1000 -seed weight was found higher in main crop than in double crop. This might be due to the long vegetative growth period, long reproductive and seed filling period in main crop growing season. Zargar et al. (2011) reported that delayed planting dates can accelerate flowering, shorten vegetative and reproductive growth, reduced grain yield and oil content of soybean. Generally, long growing season allows plants to accumulate more dry matter through more vegetative growth. Whigham and Minor (1978) reported that differences in day length result in responses in term of the number of days to flower, the number of days to maturity, plant height, seed weight, pod number, branch number and node number. As explained above by some researchers, growing period of soybean varieties is shorter and dry matter accumulation is lower in short-day conditions. The dry matter accumulation in soybean seed depends on the length of seed filling period, vegetative growth and the rate of the dry matter production (Brun, 1978). Soybean plant has shorter vegetative growth in short photoperiod with high temperature in double crop and it has longer vegetative growth in long photoperiod with low temperature in main crop growing season. Board et al. (1992) reported that delayed planting reduced the number of days to flowering and also reduced the number of days to maturity and decreased the length of regulative and reproductive periods of development. In double crop growing season, the rate of dry matter production is lower and pod filling period is shorter due to short day condition. For these reasons, the 1000-seed weight was found lower in double crop growing season.

The 1000-seed weight was varied between 167.4$190.5 \mathrm{~g}$ in main crop and between 129.8-153.4 $\mathrm{g}$ in double crop growing season (Table 3 ). The results indicated that growing seasons had significant effect on 1000-seed weight. Main and double crop growing season compared for the 1000-seed weight of soybean varieties, all of them have higher weight in main crop than in double crop. Sadeghi and Niyaki (2013) reported that different soybean varieties are sensitive to change to environment conditions where the crop is being grown. Early maturing varieties are more sensitive to photoperiod than late varieties. For this reason, the differences between the varieties for the 1000-seed weight were found significant. Rehman et al. (2014) reported that the average seed weight from early sowing was higher than that from late sowing. Early planted varieties got more time and growth period to accumulate more photo-assimilates. Growing season $\mathrm{x}$ variety interaction on 1000-seed weight of soybean was statistically significant. The highest 1000 -seed weight was obtained from Cinsoy (190.5 g) in main crop and Turksoy (153.4 g) in double crop, and the lowest from Atakisi (167.4 g) and Sa-88 (129.8 g) in main and double crop growing seasons, respectively (Table 3 ). These results are matched with the findings of Whigham and Minor (1978), Kang et al. (1998), Pedersen and Lauer (2004), Caliskan et al. (2007), Sadeghi et al. (2013), Puteh et al. (2013) and Matsuo et al. (2016).

\section{Seed yield}

There was a statistically significant difference between the growing seasons for the seed yield. The average seed yield values was found $4616 \mathrm{~kg} \mathrm{ha}^{-1}$ in main crop and $4164 \mathrm{~kg} \mathrm{ha}^{-1}$ in double crop growing seasons. The seed yield in main crop was higher when compared to double crop (Table 3). The growth and development of soybean plant is affected by the environmental factors such as temperature and photoperiod. $\mathrm{Hu}$ and Wiatrak (2012) reported that delayed planting date and unfavorable environmental conditions have a negative effect on soybean growth, development and yield. Changes in 
photoperiod, temperature and precipitation with delayed planting affect the duration of vegetative and reproductive stages, number of branches and pods, plant height, leaf area index and grain yield. These two researchers also reported that photoperiod is one of the most important environmental factors, because it regulates the whole developmental processes of soybean plant. Shortened vegetative and reproductive stages due to changes in photoperiod with delayed planting, contribute to yield loss.

Whigham and Minor (1978) reported that differences in day length result in responses in term of the number of days to flower, the number of days to maturity, plant height, seed weight, pod number, branch number and node number. Zargar et al. (2011) reported that delayed planting dates can accelerate flowering, shorten vegetative and reproductive growth, reduced grain yield and oil content of soybean. Generally, long growing season allows plants to accumulate more dry matter through more vegetative growth. Caliskan et al. (2007) reported that seed yield reduction in late planted soybean was attributed to shorter day length. Sadeghi and Niyaki (2013) reported that the soybean cultivars with early sowing (April 30) produced gave higher yield and quality as compared to the late sowing date (May 20).

As mentioned above by some researchers, growing period of soybean varieties is shorter and dry matter accumulation is lower in short-day conditions. The dry matter accumulation in soybean seed depends on the length of seed filling period, vegetative growth and the rate of the dry matter production (Brun, 1978). Soybean plant has shorter vegetative growth in short photoperiod with high temperature and longer vegetative growth in long photoperiod with low temperature. The rate of dry matter production is higher and pod filling period is longer due to long-day conditions in main crop growing season. The growing period was about 135 days in main crop and 120 days in double crop growing seasons. For these reasons, the seed yield per hectare was found higher in main crop growing season.

As it can be seen in Table 3, the average seed yield values of soybean varieties varied between $4288-5377 \mathrm{~kg}$ $\mathrm{ha}^{-1}$ in main crop and 3194-4667 $\mathrm{kg} \mathrm{ha}^{-1}$ in double crop growing seasons. The differences between the soybean varieties for the seed yield were found significant in both growing seasons. The seed yield of tested varieties was found higher in main crop than in double crop. The effect of growing seasons on seed yield of soybean varieties was markedly different. Sadeghi and Niyaki (2013) reported that different soybean varieties are sensitive to change to environment conditions where the crop is being grown. Early maturing varieties are more sensitive to photoperiod than late varieties. For this reason, the differences between the varieties for the seed yield were found significant. Rehman et al. (2014) reported that the average seed weight from early sowing was higher than that from late sowing. Early planted varieties got more time and growth period to accumulate more photo-assimilates.

Soybean seed yield is calculated by multiplying the plant number per unit area $\mathrm{x}$ pod number per plant $\mathrm{x}$ seed number per pod $\mathrm{x}$ average seed weight. Generally, soybean seed yield depends mostly on pod number per unit area and seed weight (Ohyama et al. 2013). These two factors are chances by the environment factories which are grown. It can be seen in Table 3, pod number per plant and 1000-seed weight of soybean varieties were affected by the growing season, and these data were found higher in main crop than in double crop. For these reason, the seed yield of soybean varieties was found higher in main crop compared to double crop. Growing season $\mathrm{x}$ variety interaction on seed yield of soybean was statistically significant. The highest seed yield was obtained from Atakisi (5377 kg ha ${ }^{-1}$ ) and Arisoy (4667 kg $\mathrm{ha}^{-1}$ ) and the lowest from Cinsoy (4288 $\mathrm{kg} \mathrm{ha}^{-1}$ ) and Turksoy (3194 kg ha-1) in main and double crop growing seasons, respectively (Table 3). These findings are supported by Oplinger and Philbrook (1992), Caliskan et al. (2007), Zargar et al. (2011), Sadeghi and Niyaki (2013), Puteh et al. (2013), Rehman et al. (2014) and Matsuo et al. (2016).

\section{Protein content}

The average protein content of soybean varieties was $36.6 \%$ in main crop and 37.6 in double crop growing season. The difference between the growing seasons was significant for protein content. The protein content of soybean varieties was found higher in double crop than in main crop (Table 4). Kane et al. (1997) reported that environmental conditions during soybean seed-fill, primarily temperature, can affect protein and oil content, and delayed planting increased protein content and reduced oil content. Gibson and Mullen (1996) reported that soybean seed protein and oil composition are influenced by environment during seed development. It is well known that growth temperature affects the protein and oil concentration of soybean seed. Protein and oil content vary in an inverse relation with changes in growth temperature. (Wolf et al.,1982). Breened et al. (1988) and Hurburgh et al. (1990) reported that the protein concentration of soybean produced in the southern USA in generally greater than that of soybean produced in northern locations. Bellaloui et al. (2011) reported that under irrigated condition, early planting increased seed oil (up to $16 \%$, but decreased protein (up to 6.6\%) compared to late planting. Bellaloui et al. (2015) reported that late planting resulted in higher protein and lower oil concentration in soybean seeds. As explained by some researchers above, environmental conditions during seedfill, primarily air temperature, can affect protein and oil content of soybean seed. 
Table 4. The data belonging to protein content, oil content and oil yield per hectare of two years (2013-2014) average values of some soybean varieties grown in different season

\begin{tabular}{|c|c|c|c|c|c|c|}
\hline \multirow{3}{*}{ Varieties (A) } & \multicolumn{2}{|c|}{$\begin{array}{c}\text { Protein content } \\
(\%)\end{array}$} & \multicolumn{2}{|c|}{$\begin{array}{c}\text { Oil content } \\
(\%)\end{array}$} & \multicolumn{2}{|c|}{$\begin{array}{l}\text { Oil yield } \\
\left(\mathrm{kg} \mathrm{ha}^{-1}\right)\end{array}$} \\
\hline & \multicolumn{6}{|c|}{ Growing seasons (B) } \\
\hline & Main Crop & Double Crop & Main Crop & Double Crop & Main Crop & Double Crop \\
\hline Arisoy & 36.7 & 37.4 & 19.4 & 18.6 & 1046 & 898 \\
\hline Atakisi & 37.6 & 38.2 & 19.9 & 19.3 & 1144 & 900 \\
\hline Ataem-7 & 37.6 & 38.5 & 18.6 & 18.1 & 947 & 690 \\
\hline Umut-2002 & 37.6 & 38.5 & 18.0 & 17.5 & 890 & 759 \\
\hline Turksoy & 37.6 & 37.9 & 19.0 & 18.2 & 895 & 582 \\
\hline Adasoy & 36.6 & 37.5 & 20.0 & 19.4 & 960 & 802 \\
\hline Cinsoy & 36.7 & 37.6 & 18.5 & 17.5 & 773 & 751 \\
\hline Ilksoy & 36.6 & 37.6 & 17.7 & 17.1 & 806 & 726 \\
\hline Sa-88 & 35.6 & 37.2 & 18.9 & 18.1 & 930 & 708 \\
\hline S.4240 & 35.4 & 37.0 & 19.8 & 19.2 & 993 & 846 \\
\hline Blaze & 35.0 & 36.9 & 19.3 & 18.0 & 900 & 722 \\
\hline Nova & 35.6 & 36.7 & 19.0 & 18.2 & 882 & 777 \\
\hline Average & 36.6 & 37.6 & 19.0 & 18.3 & 877 & 761 \\
\hline $\operatorname{LSD}\left(\% 5_{\mathrm{A}}\right)$ & 0.16 & 0.34 & 0.55 & 0.88 & 58.68 & 54.55 \\
\hline $\operatorname{LSD}\left(\% 5_{\mathrm{B}}\right)$ & \multicolumn{2}{|c|}{0.54} & \multicolumn{2}{|c|}{0.39} & \multicolumn{2}{|c|}{42.02} \\
\hline $\operatorname{LSD}\left(\% 5_{\mathrm{AxB}}\right)$ & \multicolumn{2}{|c|}{0.26} & \multicolumn{2}{|c|}{ NS } & \multicolumn{2}{|c|}{55.05} \\
\hline
\end{tabular}

The differences between the soybean varieties for the protein content were found statistically significant in both growing seasons. The growing seasons was effected on protein content of soybean varieties. Protein content values were varied between $35.0-37.6 \%$ in main crop and $36.7-38.5 \%$ in double crop growing season. The protein content of soybean varieties was higher in double crop than in main crop. The highest protein content was obtained from Atakisi, Ataem-7, Umut-2002 and Turksoy (37.6\%) varieties in main crop and Ataem-7 and Umut$2002(38.5 \%)$ varieties in double crop growing seasons (Table 4). Wilcox and Cavin (1995) reported that seed composition constituents are genetically controlled; however, they are known to be influenced by biotic and abiotic factors such as genotype, maturity, growing season, geographic location, and agronomic practices.

Growing season $\mathrm{x}$ variety interaction on protein content of soybean was statistically significant. The highest protein content was obtained from Atakisi, Ataem7, Umut-2002 and Turksoy (37.6\%) varieties in main crop and Ataem-7 and Umut-2002 (38.5\%) varieties in double crop growing seasons. The lowest protein content was obtained from Blaze $(35.0 \%)$ in main crop and Nova $(36.7 \%)$ in double crop growing seasons (Table 4). These results are in agreement with the findings of Dornbos and Mullen (1992),Wolf et al. (1992), Gibson and Mullen (1996), Kane et al. (1997), Bellaloui et al. (2011) and Bellaloui et al. (2015).

\section{Oil content}

As it can be seen in table 4, there was statistically significant difference in oil content between soybean varieties in either growing season in a two-year average. The average oil percentage of soybean varieties was higher in main crop growing season $(19.0 \%)$ than in double crop growing season (18.3\%). In this research; the seed filling period was determined to be in between August 15-September 5 for main crop growing season and in between September 15-October 5 for double crop growing season. Gibson and Mullen (1996) reported that soybean seed protein and oil composition are influenced by environment during seed development. It is well known that growth temperature affects the protein and oil concentration of soybean seed. High temperature during the growing season was correlated with high oil content (Wolf at al., 1982). Gibson and Mullen (1996) reported that soybean seed protein and oil composition are influenced by environment during seed development. It is well known that growth temperature affects the protein and oil concentration of soybean seed. High temperature during the growing season was correlated with high oil content (Wolf at al., 1982). Howell and Cartter (1953) and Whigham and Minor (1978) reported that high air temperature occurred between 20 to 40 days before maturity, increased oil content of soybean seed. They also reported that in greenhouse studies, temperatures of $21^{\circ} \mathrm{C}$, $25^{\circ} \mathrm{C}$ and $29^{\circ} \mathrm{C}$ during the pod filling stage produced oil content with $19.5 \%, 20.8 \%$, and $23.2 \%$ in soybean. Environment plays a critical role in oil content of soybean seed (Bellaloui et al., 2015). Some other researchers reported that high air temperature mainly in pod filling period, increased oil percentage of soybean seed (Dornbos and Mullen, 1992; Kane et al., 1997; Bellaloui et al., 2011 and Bellaloui et al., 2015).

The oil content values of soybean varieties varied between $17.7-20.0 \%$ in main crop season and $17.1-19.4 \%$ in double crop growing season in a two-year average. The highest oil content was obtained from Adasoy (20.0 and $19.4 \%)$ and the lowest from Ilksoy (17.7 and $17.1 \%)$ in main and double crop growing seasons, respectively (Table 4). The oil content of soybean varieties was affected by the growing seasons. Wilcox and Cavin (1995) 
reported that seed composition constituents are controlled by genotype, maturity, growing season, geographic location, and agronomic practices. Hurburgh et al. (1990) and Breened et al. (1988) reported that the protein concentration of soybean produced in the southern USA in generally greater than that of soybean produced in northern locations, whereas oil concentration is generally greater in soybean produced in northern and western growing areas. Bellaloui et al. (2013) reported that the amount of oil in soybean seed was reported to be affected by genetics and environment especially drought and temperature/heat and their interactions. Growing season $\mathrm{x}$ variety interaction on oil content of soybean was not statistically significant. Similar results were reported by Kane et al. (1997), Wolf et al. (1982), Dornbos an Mullen (1992), Maestri et al. (1998), Gibson and Mullen (1996), Bellaloui et al. (2011) and Bellaloui et al. (2015)

\section{Oil yield}

As it can be seen in Table 4, the oil yield of soybean varieties was $877 \mathrm{~kg} \mathrm{ha}^{-1}$ in main crop and $761 \mathrm{~kg} \mathrm{ha}^{-1}$ in double crop growing seasons. There was a statistically significant difference in oil yield per hectare between the growing seasons. The oil yield was found higher in main crop than in double crop. Oil yield was calculated as the ration of seed yield $\left(\mathrm{kg} \mathrm{ha}^{-1}\right) \mathrm{x}$ oil content $(\%)$ in soybean (Gulluoglu et al., 2016). The seed yield and the oil content of soybean varieties were higher in main crop than in double crop growing season. For these reasons, the oil yield was found higher in main crop than in double crop.

The oil yield values of soybean varieties varied between $773-1144 \mathrm{~kg} \mathrm{ha}^{-1}$ in main crop and 582-900 kg $\mathrm{ha}^{-1}$ in double crop growing seasons. The difference between the varieties was significant in both growing seasons (Table 4). While the average oil yield of soybean varieties was $882 \mathrm{~kg} \mathrm{ha}^{-1}$ at main crop, it decreased to 777 $\mathrm{kg} \mathrm{ha}^{-1}$ at double crop growing seasons. The highest oil yield was obtained from Atakisi $\left(1144 \mathrm{~kg} \mathrm{ha}^{-1}\right.$ and $900 \mathrm{~kg}$ $\mathrm{ha}^{-1}$ ) in both growing seasons. The differences between the soybean varieties for the oil yield, comes from seed yield and oil content differences (Table 3 and 4). Growing season $\mathrm{x}$ variety interaction on oil yield of soybean was statistically significant.

\section{CONCLUSIONS AND SUGGESTIONS}

The growth and development of soybean plant is affected by the environmental factors such as temperature and photoperiod. Delayed planting date and unfavorable environmental conditions have a negative effect on soybean growth, development and yield. Changes in photoperiod, temperature and precipitation with delayed planting affect the duration of vegetative and reproductive stages, yield and some agronomic traits. Soybean plants are sensitive to photoperiod, and soybeans are classified as short-day plants because short days initiate the flowering process. Soybean cultivars differ in their response to day length. Differences in day length result in responses in term of the number of days to flower, the number of days to maturity, plant height, seed weight, pod number and branch number. Late maturing cultivars are more sensitive to photoperiod than are early maturing cultivars.

In this research, the effects of growing seasons on some agronomic and quality characteristics of soybean varieties (Ar1soy, Atakisi, Ataem-7, Umut-2002, Turksoy, Adasoy, Cinsoy, Ilksoy, Sa-88, S.4240, Blaze and Nova) were investigated. As a result; the characteristics such as plant height, pod and branch number per plant, the lowest pod height, 1000-seed weight, oil percentage and oil yield values of soybean varieties were higher in main crop than in double crop, whereas the protein percentage values was higher in double crop. The average seed yield of soybean varieties were $4616 \mathrm{~kg} \mathrm{ha}^{-1}$ in main crop and it was decreased to $4164 \mathrm{~kg} \mathrm{ha}^{-1}(10.9 \%)$ in double crop growing season. The average seed yield was higher in main crop than in second crop. According to a two-year average, the seed yield per hectare of soybean varieties was varied between $4288-5377 \mathrm{~kg} \mathrm{ha}^{-1}$ in main crop and 3194-4667 $\mathrm{kg} \mathrm{ha}^{-1}$ in double crop growing season, and the highest seed yield was obtained from Atakisi and Arisoy varieties in both growing seasons. The oil content was (19.0\%) higher in main crop than in double crop (18.3\%), whereas the protein content was higher in double crop (37.6\%) than in main crop $(36.6 \%)$ growing seasons. According to these results, main crop production is better for oil production, whereas double crop production is better for animal feeding (full-fat).

\section{LITERATURE CITED}

Anonymous, 2015. FAO Production Year Book (www.fao.org).

Anonymous, 2015. The Meteorological Data for Adana. The Turkish State Meteorological Service. Adana Regional Directorship, 2013, 2014 and Long Term.

AOAC. 2010. Official Methods of Analysis of the Association of Analytical Chemists. $18^{\text {th }}$ Edition, Washington, D.C. USA

Arioglu, H. H. 2014. The Oil Seed Crops Growing and Breeding. The Publication of University of Cukurova, Faculty of Agriculture, No:A-70, 204 p. Adana-Turkey

Bellaloui, N., K.N. Reddy, A.M. Gillen, D.K. Fisher and A. Mengistu. 2011. Influence of Planting Date on Seed Protein, Oil, Sugars, Minerals, and Nitrogen Metabolism in Soybean under Irrigated and Non-irrigated Environments. American J. Plant Sci. 2(5):702-705

Bellaloui, N., A.M. Mengistu and My.A. Kassem. 2013. Effects of Genetics and Environment on Fatty Acid Stability in Soybean Seed. Food and Nutrition Sciences, 4:165-175

Bellaloui, N., H.A. Bruns, H.K. Abbas, A. Mengistu, D.K. Fisher and K.N. Reddy. 2015. Agricultural Practices Altered Soybean Seed Protein, Oil, Fatty Acids, Sugars, and Minerals in the Mid-south USA. Front Plant Science 6:31, Doi: $10.3389 /$ fpls.2015.00031

Board, J.E., M. Kamal and B.G. Harville. 1992. Temporal Importance of Greater Light Interception to Increase Narrow-row Soybean. Agronomy Journal, 84:575-579

Breene, W.M., S. Lin, L. Hardman and J. Orf. 1988. Protein and Oil Content of Soybeans from Different Geographic Locations. Journal of the American Oil Chemists' Society, 65 (12):1927-1931.

Brun, W.A. 1978. Assimilation. Soybean Agronomy, Physiology and Utilization. Geoffrey Norman, A. (Ed)., Academic Press, London. pp. 45-73 \& 249.

Caliskan, S., M. Arslan, I. Uremis and M.E. Caliskan. 2007. The Effects of Row Spacing on Yield and Yield Components of 
Full Season and Double Cropped Soybean. Turk J. Agric. and For. 31:147-154

Chu, W.S and V.L. Sheldon. 1979. Soybean Oil Quality as Influenced by Planting Site and Variety. J. of the American Oil Chemists Society (JAOCS). 56(2):71-73.

Dombos, D.L and R.E. Mullen. 1992. Soybean Seed Protein and Oil Contents and Fatty Acid Composition Adjustments by Drought and Temperature. J. American Oil Chem. Soc. (JAOCS). 69(3): 228-231.

Gibson, L.R and R.E. Mullen. 1996. Soybean Seed Composition under High Day and Night Growth Temperature. J. of the American Oil Chemists' Society (JAOCS), 73(6): 733-737 .

Gulluoglu, L., H. Bakal and H. Arioglu. 2016. The Effects of Twin-row Planting Pattern and Plant Population on Seed Yield and Yield Components of Soybean at Late DoubleCropped Planting in Cukurova Region. Turkish Journal of Field Crops, 21(1):59-65

Hicks, D.R. 1978. Growth and Development. Soybean Agronomy, Physiology and Utilization. Geoffrey Norman, A. (Ed)., Academic Press, London. pp. 17-41 \& 249.

Howel, R.W and J.L. Cartter. 1953. Physiological Factors Affecting Composition of Soybean. I. Correlation of Temperature During Certain Portions of The Pod Filling Stage with Oil Percentage in Mature Beans, Agron.J. 45:526-528

Hurburgh, Jr., C.R., T.J. Bruum, J.M. Guin and R.A. Hartwig. 1990. Protein and Oil Patterns in U.S. and World Soybean Markets, J. Am. Oil Chem. Soc. 67:966-973.

$\mathrm{Hu}, \mathrm{M}$ and P. Wiatrak. 2012. Effect of Planting Date on Soybean Growth Yield and Grain Quality: Review. Agronomy Journal, 104(3): 785-790

Kane, M.V., C.C. Steel, L. Grabau, C.T. Mac Kown and D.F. Hildebrand. 1997. Early-Maturing Soybean Cropping System: III. Protein and Oil Contents and Oil Composition. Agron. J. 89(3): 464-469.

Kang, Y.K., M.R. Ko, N.K. Cho and Y.M. Park. 1998. Effect of Planting Date and Planting Density on Growth and Yield of Soybean in Cheju Island. Korean J. of Crop Science, 43(4):44-48

Maestri, D.M., D.O. Labuskas, C.A. Guzman and L.M. Giorda. 1998. Correlation Between Seed Size, Protein and Oil Contents and Fatty Acid Composition in Soybean Genotypes. Grasas y Aceites, 49 (5-6):450-453

Matsuo, N., K.Fukami and S.Tsuchiya. 2016. Effects of Early Planting and Cultivars on the Yield and Agronomic Traits of Soybeans Grown in Southwestern Japan. Plant Production Science, 19(3):370-380
Minor, H.C. 1976. Planting Date and Plant Spacing in Soybean Production. Expanding The Use of Soybeans (Proceedings of a Conference for Asia and Oceania). INTSOY Series, 10:5662

Ohyama, T., R. Minagawa, S. Ishikawa, M. Yamamoto, N.Van Phi Hung, N. Ohtake, K. Sueyoshi, T. Sato, Y. Nagumo, and Y. Takahasi. 2013. Soybean Seed Production and Nitrogen Nutrition. http:/dx.doi.org/10.5772/45867

Oplinger, E.S. and B.D. Philbrook.1992. Soybean Planting Date, Row Width and Seeding Rate Response in Three Tillage Systems. J. Prod. Agric., 5(1):94-99

Pedersen,R. and J.G.Lauer. 2003. Soybean Agronomic Response to Management Systems in the Upper Midwest. Agronomy Journal, 95:1146-1151

Puteh,A.B., M. ThuZar, M.M.S. Mondal, N.A.P.B. Abdullah and M.R.A. Halim. 2013. Soybean [Glycine max (L.)Merrill] Seed Yield Response to High Temperature Stress During Reproductive Growth Stages. Australian J. of Crop Science, 7(10):1472-1479

Rehman,M., T. Khaliq, A. Ahmad, S.A. Wajid, F. Rasul, J. Hussain and S. Hussain. 2014. Effect of Planting Time and Cultivar and Soybean Performance in Semi-arid Punjab, Pakistan. Global J. of Science Frontier Research: Agriculture and Veterinary, 14(3-1.0):41-45

Sadeghi, S.M and S.A. Niyaki. 2013. Effects of Planting Date and Cultivar on the Yield and Yield Components of Soybean in North of Iran. ARPN journal of Agricultural and Biological Science, 8(1):81-85

Whigham, D.K and H.C. Minor. 1978. Agronomic Characteristics and Environmental Stress. Soybean Agronomy, Physiology and Utilization. Geoffrey Norman, A. (Ed.), Academic Press, London. pp. 78-116, 247p.

Wilcox, J.R. and J.F. Cavin. 1995. Backcrossing High Seed Protein to a Soybean Cultivar. Crop Science 35:1036-1041

Wolf, R.B., J.F. Cavins, R. Kleiman and L.T. Black 1982. Effect of Temperature on Soybean Seed Constituents: Oil, Protein, Fatty Acids, Amino Acids and Sugars. J. American Oil Chem Soc. (JAOCS), 59(5): 230-232.

Zaimoglu, B., H.H. Arioglu and M. Aslan. 2004. Effects of Seed Quality on Plant Population and Seed Yield of Double Cropped Soybean in the Mediterranean Region of Turkey. Asian Journal of Plant Science, 3 (5):574-577.

Zargar, M., S. Mafakheri and M.J. Shakouri. 2011. Response of Soybean Varieties to Different Planting Dates. Middel-East J. of Scientific Research, 8(1):161-164 